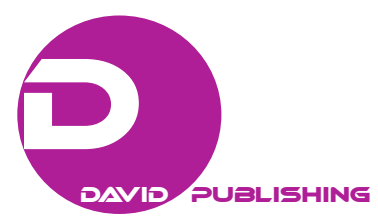

\title{
A Study on the Activities During the Fuzzy Front End in New Product Development Projects of Korean ICT Firms
}

\author{
Heeja Yoon \\ Tohoku University, Sendai, Japan \\ Jeonglim Yun \\ Seoul National University of Science and Technology, Seoul, Korea \\ Akio Nagahira \\ Ritsumeikan University, Kyoto, Japan \\ Shuichi Ishida \\ Tohoku University, Sendai, Japan
}

\begin{abstract}
Although previous studies on Korean manufacturing firms have empirically analyzed the causal relationship between activities during the FFE (Fuzzy Front End) and success of NPD (New Product Development) of Korean manufacturing firms, no study has concretely focused on Korean ICT (Information and Communications Technology) firms and their FFE activities. The main aim of this study is to identify the activities of these firms during their FFE and provide managerial insights into the other ICT firms. The authors conducted a survey (106 valid responses) that their FFE activities on new product development project managers in Korean ICT firms. The results showed that even though new product development managers of Korean ICT firms did not search for ideas systemically, they communicated with those departments/divisions that had frequent interaction with customers for idea assessment, with the active involvement of middle- or higher-level managers. They thoroughly established initial plans in the pre-development stages and seriously analyzed competitors' products and direct and indirect customer interactions in their market survey activities.
\end{abstract}

Keywords: Korean ICT firms, new product development, project manager, fuzzy front end activities

\section{Background and Objectives}

Many Korean ICT firms, such as Samsung Electronics, LG Electronics, and SK Hynix, have achieved a large market share in the global market. A 2016 report that compiled the top-ten export items from all industries in Korea (2017 Annual Report on the Promotion on the Korean ICT Industry, 2018a) showed that

Heeja Yoon, Ph.D. candidate, Management Science and Technology Department, Graduate School of Engineering, Tohoku University, Sendai, Japan.

Jeonglim Yun, Ph.D. candidate, Graduate School of Public Policy and Information Technology, Seoul National University of Science and Technology, Seoul, Korea.

Akio Nagahira, Ph.D., professor, Graduate School of Technology Management, Ritsumeikan University, Kyoto, Japan..

Shuichi Ishida, Ph.D., professor, Management Science and Technology Department, Graduate School of Engineering, Tohoku University, Sendai, Japan.

Correspondence concerning this article should be addressed to Heeja Yoon, Tohoku University, 6-6-11-802 Aza-Aoba, Aramaki, Aoba-ku, Sendai, 980-8579, Japan. 
many ICT products led the economy: semiconductors (1st place), wireless communications devices (4th place), flat panel displays (6th place), and computers (11th place). As such, the Korean ICT industry has a huge spillover effect on the whole economy, with its contribution to the GDP (Gross Domestic Product) reaching as high as $15.3 \%$ (as of 2016). Hence, the Korean ICT industry is critical to maintaining national competitiveness in the global economy.

However, few studies have investigated how the Korean ICT industry achieved such high competitiveness in the global market. Kim and Yoon's (2011) study of the Korean manufacturing firms addressed this research question and found that the high competitiveness of Korean firms in the global market based on their activities during the FFE (Fuzzy Front End) stages in NPD (New Product Development), with FFE activities positively affecting NPD success. Since then, studies have examined and compared the FFE activities of manufacturing firms in Korea and Japan (Nagahira et al., 2015; Mammetseyidov \& Nagahira, 2015). Although these studies reveal that Korean manufacturing firms focus more on reducing market uncertainties than technological uncertainties during the FFE stages, their limitation is that they did not identify which activities were to be implemented by NPD project managers for initial plans, and how to reduce market and technological uncertainties.

In addition, these studies do not identify the characteristics of FFE activities by industry because they examine manufacturing firms across all industries. To address these limitations, this study aims to reveal FFE activities by project managers of the ICT firms and suggest insights for managing the FFE activities of NPD projects and improving competitiveness. To this end, the authors conducted a survey of Korean ICT firms regarding their specific activities during FFE, which were not examined by previous studies (Table 1).

The survey was conducted for three months, from November 2017 to January 2018, and it focused on individual NPD projects rather than individual firms as the target of this analysis. Therefore, the subjects of this survey were NPD project managers at Korean ICT firms. In this survey, the authors made use of survey questions developed by Herstatt, Verworn, and Nagahira (2004), who compared FFE activities between Germany and Japan. No modification was done to these survey questions, as the present study was a comparison among firms in Korea, Germany, and Japan.

This paper is organized as follows. Chapter 1 deals with the background and objectives of this study. Chapter 2 reviews previous studies on FFE activities in Korea. In Chapter 3, the authors discuss methods and technical analysis results of this study, with the conclusion in Chapter 4. Chapter 5 discusses the limitations and future direction of this study.

Table 1

Classification of the Korean Information and Communications Technology (ICT) Industry

\begin{tabular}{ll}
\hline ICT manufacturing & ICT services \\
\hline Semiconductor & ICT wholesale trade \\
\hline Electronic parts & Leasing or rental services for ICT equipment \\
\hline Computer and peripheral equipment & Telecommunications \\
\hline Communications and broadcasting equipment & ICT computer programming system comprehensive management \\
\hline Video and audio equipment & ICT information service industry \\
\hline Magnetic and optical media & ICT repair services \\
\hline
\end{tabular}

Source: Ministry of Science and ICT (2018b), "Information and Communication Technology Industry Statistics". 


\section{Previous Studies on FFE Activities in Korea}

Of the studies that claimed that a successful NPD is determined by specific actions in the development process, Cooper and Kleinschmidt (1987), Dwyer and Mellor (1991), and Wind and Mahajan (1988) suggested that the NPD process is a tool to achieve corporate competitiveness, and companies that effectively perform activities in the NPD process show better results.

Cooper (1988) disserted that pre-development activities were important in the NPD process and the success or failure of NPD is determined by these activities. The Fuzzy Front End (FFE) stage is also called the pre-development stage (Cooper, 1988) or pre-phase zero stage (Khurana \& Rosenthal, 1998). Cooper and Kleinschmidt (1994) suggest that the quality of FFE activities determines the difference between winners and losers in corporate competitiveness. Efforts in the FFE stages are important because they affect the overall innovation process (Smith \& Reinertsen, 1991; Verganti, 1999).

Herstatt et al. (2004) divided the NPD process into idea generation and assessment (Phase I); concept development and planning (Phase II); development (Phase III); prototype development and testing (Phase IV); and production, market introduction, and diffusion (Phase V). They did a comparative study of activities in German and Japanese firms to reduce uncertainty during FFE in innovation projects: The results showed that Japanese firms achieved efficiency through a strict control system, while German firms did not systematically implement a management method or procedure.

The results revealed that German firms had already integrated functions related to R\&D, marketing, sales, production, and customer service and considered important information and planning changes in the idea generation phase; they went on to improve efficiency as they had reduced uncertainty and discrepancies after implementation. Although some studies had highlighted the importance of FFE in NPD projects, there were few empirical studies in the early 2000s. However, Verworn et al. (2008) identified the causal relationship between FFE and successful NPD through large-scale surveys in the Japanese manufacturing industry and clarified that Japanese firms also used the FFE process.

Professor Nagahira who led this study (Verworn, Nagahira, \& Ishida, 2008) explored whether the Korean firms had already applied the FFE process, as it could be the reason for their competitiveness in the global market. Nakata, Im, Park, and Ha (2006) concluded that Korean firms did not use the FFE process in the 2000s. However, Nagahira's joint research team surveyed Korean manufacturing firms and concluded that these firms had a FFE process in place. These FFE activities showed a positive effect on the success of NPD projects when the firms focused more on the reduction of market uncertainties than technological uncertainties (Kim \& Yoon, 2011; Nagahira et al., 2015; Yoon, Nagahira, \& Ishida, 2016).

Nagahira et al. (2015) clarified the characteristics of the Korean manufacturing industry in a comparative study of FFE activities in Japanese and Korean manufacturing firms and indicated that the Korean firms focused more on reducing market uncertainties than technological uncertainties when compared with their Japanese counterparts. Meanwhile, Mammetseyidov and Nagahira (2015) used Japanese data (540 firms) and Korean data (293 firms) from Kim and Yoon (2011) and conducted a comparative study between Korea and Japan based on their FFE activities and changes in project implementation.

The results made it clear that reducing market uncertainties in the initial planning stages positively contributed to the success of NPD in both countries. Notably, they argued that the reason for successful NPD projects in Korean firms was a flexible system for project implementation, which allowed these firms to change 
initial plans with changes in the market environment.

As described above, studies on FFE in Korea have identified a causal relationship between FFE activities and successful NPD through empirical analysis, but these studies do not mention the specific activities performed by firms in the FFE phase. However, Herstatt et al. (2004) examined specific activities of Japanese manufacturing firms in the FFE phase. Table 2 shows the survey questions developed by Herstatt et al. (2004) without any modification.

Table 2

Operational Definition of Fuzzy Front End (FFE) Activities

\begin{tabular}{lll}
\hline FFE activities & Survey questions & Literature \\
\hline & 1. Does your company systematically search for new product ideas? & \\
& Where does your company search for new product ideas/Is there an individual & Baker et al. (1985), \\
& person or a group of people in your company?/responsible for the systematic & Geschka (1992), \\
Idea & search for new products/Do you use a database to store and process ideas for & Herstatt et al. (2004), \\
generation & new products? & Rochford (1991), \\
& 2. Please mark all creative techniques your company consistently applies to & Rubinstein (1994), \\
& develop new product ideas. & Song and Parry (1997) \\
& Brainstorming/Value analysis/Kaizen/Others & \\
\hline
\end{tabular}

1. In your company, are new product ideas typically assessed by an individual or a group?

2. Is upper management typically involved in assessing new product ideas?

3. Are new product ideas assessed by an interdisciplinary team?

Cooper and

If yes, which functions are typically represented in such a team?

Kleinschmidt (1986;

1994),

Dwyer and Mellor (1991),

Idea Marketing/Research and Development/Sales/Customer Service/Others

assessment 4. Do you use technical criteria in your company to assess new product ideas?

If yes, please mark all technical criteria regularly used in your company to

Herstatt et al. (2004),

Johne and Snelson (1988), assess new product ideas.

Technical feasibility/Availability of required technology inside your firm/Others

Mishra et al. (1996),

Song and Parry (1996; 1997),

Mansfield and Wagner (1975),

5. Do you weigh such different (economic and technical) criteria according to

Song and Montoya-Weiss (2001) their importance? ("Scoring")

1. How often are you in direct contact with customers/users to develop and evaluate new product ideas?

If you have frequent contact, which functional department in your company contacts customers/users?

Marketing/Research and Development/Application Engineering/After

Sales/Customer Service/Others

2. According to which criteria do you select customers/users you contact to develop and evaluate new ideas?

The degree to which the customer/user is dissatisfied with existing products/Motivation of the customer/User to solve the problem he or she has

Market

research activities with existing products/Knowledge of the customer/user (e.g., sales volume)/A good relationship with the customer/User (e.g., with regard to secrecy)/Others/No criteria are used

3. Please mark all market-related sources your company uses to develop new product ideas.

Direct contact with customers/Customer complaints/Customer surveys/Market study or market research carried out by external entities/Analysis of competitors and their products/Others

4. Does your company systematically integrate customer requirements into the definition of the new product concept?

5. Does your company systematically translate customer requirements into technical specifications?

If yes, which method or tool do you use?

None/Quality Function Deployment (QFD)/TRIZ $1 /$ Others

Balbontin et al. (1999; 1994),

Cooper and Kleinschmidt (1990), Herstatt et al. (2004),

Khurana and Rosenthal (1997),

Maidique and Zirger (1984),

Song and Parry (1996),

Mullins and Sutherland (1998)

\footnotetext{
1 TRIZ (theory of solving inventive problems).
} 
Table 2 to be continued

\begin{tabular}{|c|c|c|}
\hline $\begin{array}{l}\text { Technical } \\
\text { activities }\end{array}$ & $\begin{array}{l}\text { 1. Which of the following methods or tools does your company typically apply } \\
\text { during pre-development? } \\
\text { Simulation/Virtual reality techniques/Rapid prototyping (e.g., } \\
\text { stereolithography)/Early physical prototyping/Others/None }\end{array}$ & $\begin{array}{l}\text { Herstatt et al. (2004), } \\
\text { Moenaert et at. (1995), } \\
\text { Song and Montoya-Weiss } \\
(2001) \text {, } \\
\text { Song and Parry (1996) }\end{array}$ \\
\hline $\begin{array}{l}\text { Initial project } \\
\text { planning }\end{array}$ & $\begin{array}{l}\text { 1. Does your company systematically plan a project prior to the start of } \\
\text { development? } \\
\text { If yes or at least sometimes, which of the following information does such } \\
\text { initial planning typically include? } \\
\text { Milestones with defined deliverables/Work packages/Cost plan/Required staff } \\
\text { for the project/Bar charts (Gantt charts)/Network diagrams } \\
\text { 2. Does your company use project management software? } \\
\text { If yes, which software? }\end{array}$ & $\begin{array}{l}\text { Balachandra and Friar (1997), } \\
\text { Herstatt et al. (2004), } \\
\text { Maidique and Zirger } \\
\text { (1984), } \\
\text { Pinto and Slevin } \\
\text { (1988), } \\
\text { Song and Parry (1996) }\end{array}$ \\
\hline
\end{tabular}

\section{Methods and Results}

\section{Methods}

This study distributed questionnaires to project managers and higher-level managers in charge of NPD projects at Korean ICT firms by e-mail and collected their responses. The respondents' included startups, small-sized, medium-sized, and large-sized firms, and their affiliates. Questionnaires were delivered to 130 NPD project managers at ICT firms, and 109 responses were collected. Of these, 106 responses were considered valid after excluding those with many missing values.

This study analyzed projects and requested responses from various project managers after considering the execution of multiple projects in large firms.

The survey questionnaire on FFE activities consisted of 15 items and sub-questions (Table 2), and we allowed multiple responses for some items.

\section{Descriptive Statistics and Analysis Results}

Overview of respondent firms. Figure 1 presents a schematic graph that shows the annual sales of the respondent firms in 2016. Figure 2 is a bar graph showing the size of responding firms. 21 firms (33.9\%) have the number of employees with less than 50 employees, followed by 13 firms (21\%) with fewer than 300 employees. $54.8 \%$ of responding firms with less than 300 respondents shared more than half of them.

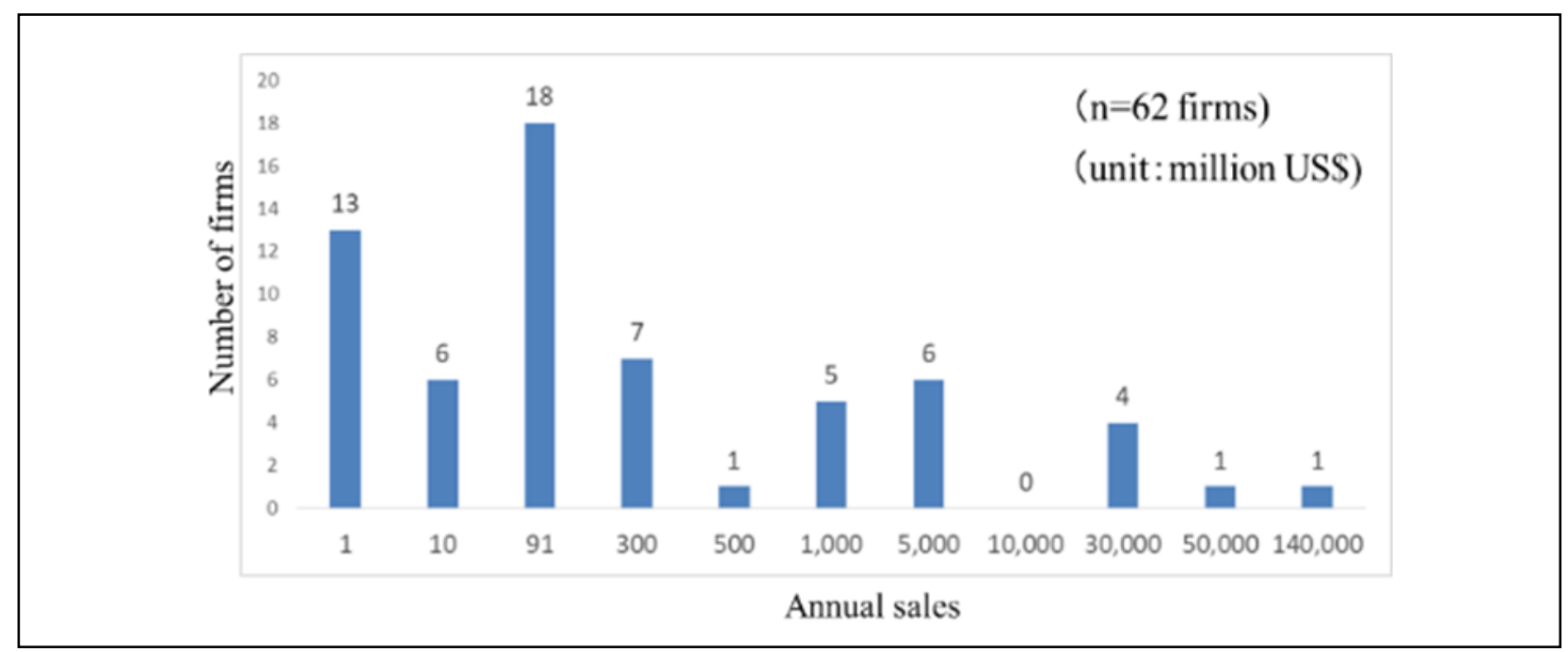

Figure 1. Annual sales. 


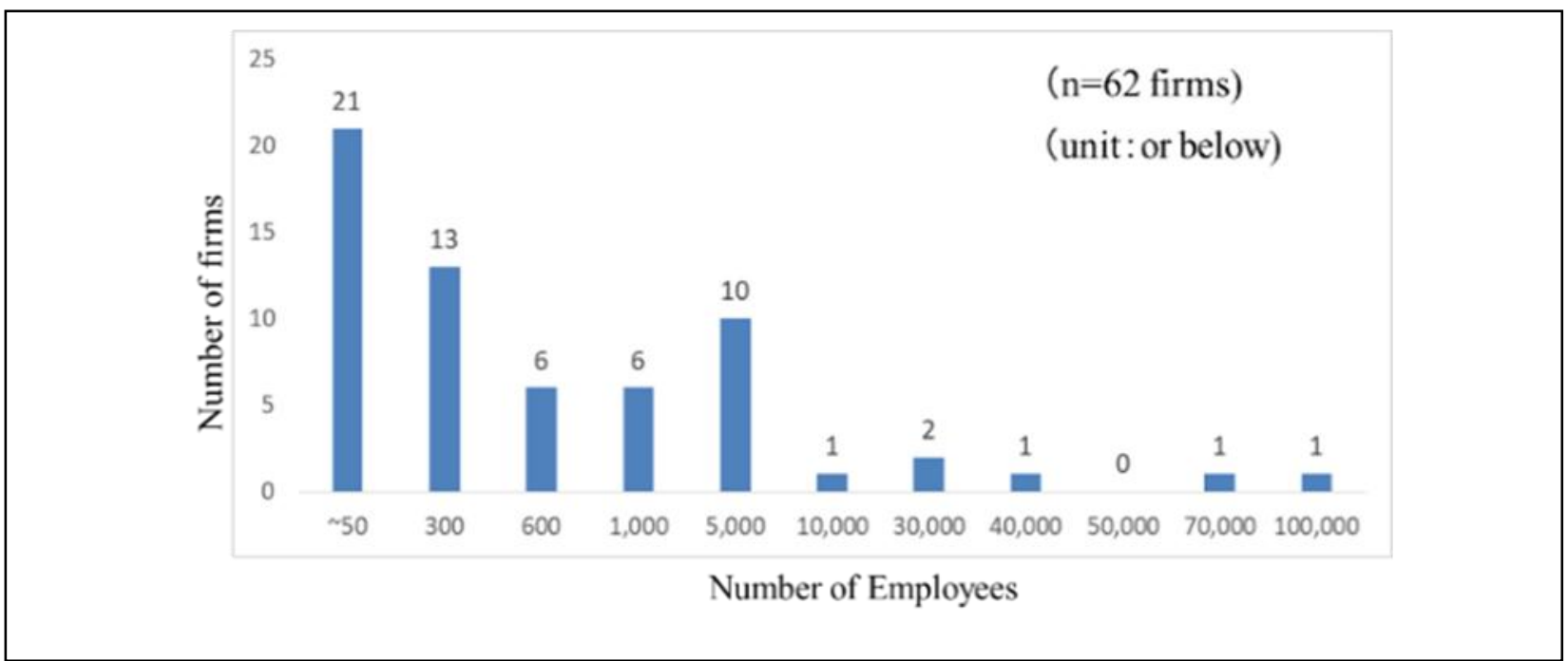

Figure 2. The number of employees.

Figure 3 is a pie chart that shows the size of the respondents' firms $(n=63)$ : Small firms accounted for 35 $(55.6 \%)$ of the total, 11 for large firms (17.5\%), 10 for middle-sized firms (15.9\%), and 7 for large-firm affiliates (11.1\%).

Figure 4 is a pie chart that shows the number of project managers $(n=106)$ : Large firms accounted for 43 of the respondents (40.6\%), followed by small firms with 37 (34.9\%), large-company affiliates with 15 (14.2\%), and medium-sized firms with $11(10.4 \%)$.

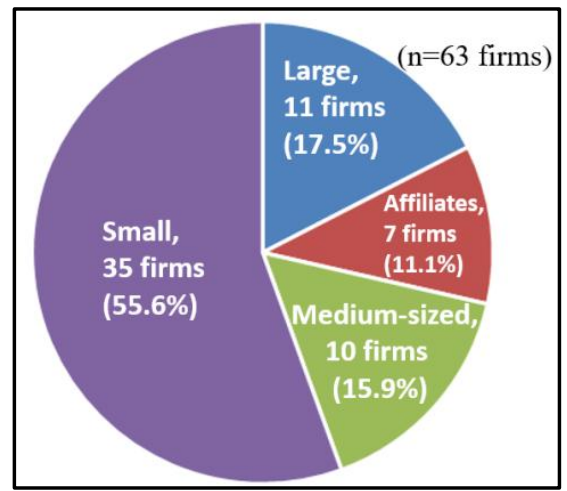

Figure 3. Size of the respondents' firms.

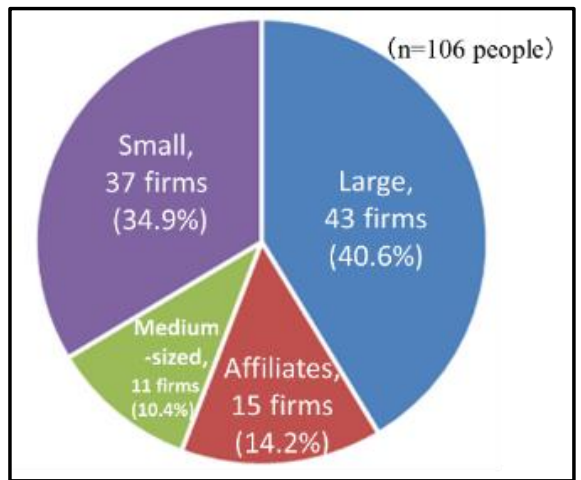

Figure 4. The number of the respondents by firm size. 
Figure 5 shows the departments to which the respondents belong: Strategy and Planning accounted for 38 respondents, followed by R\&D with 23, Marketing with 13, Sales with 6, Others with 11, and Multiple Posts with 11. Figure 6 details the titles of the respondents; there were 24 General Managers, followed by 23 Deputy General Managers, 15 Directors, and 11 CEOs.

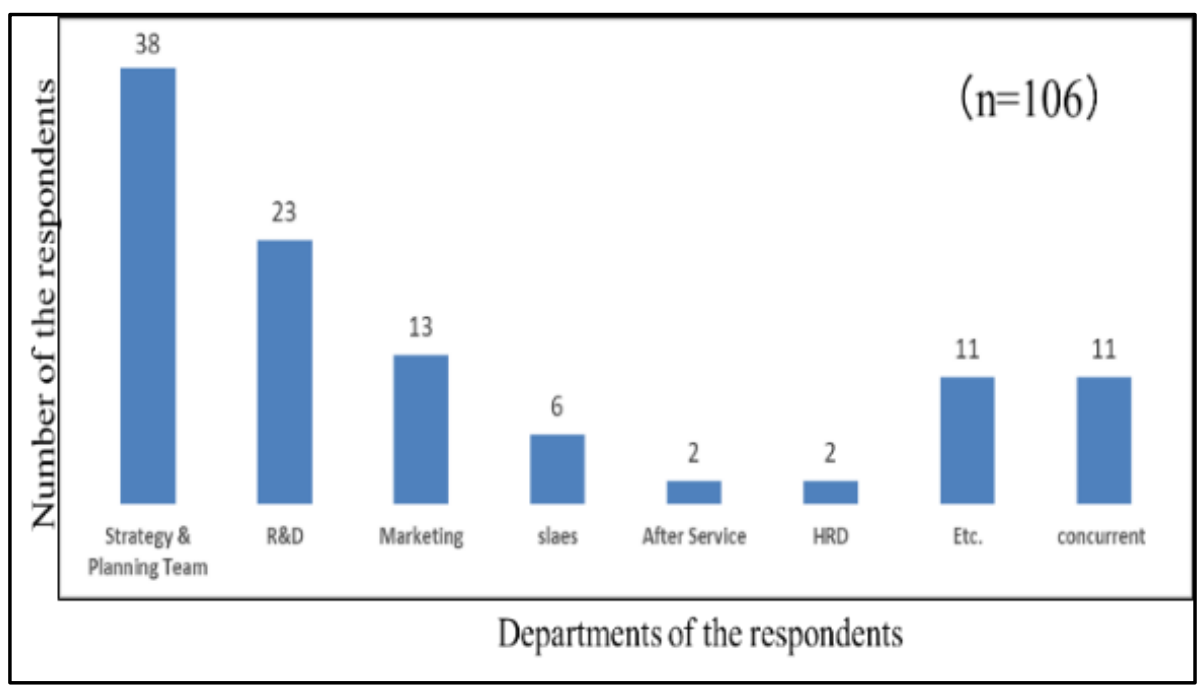

Figure 5. Department of the respondents.

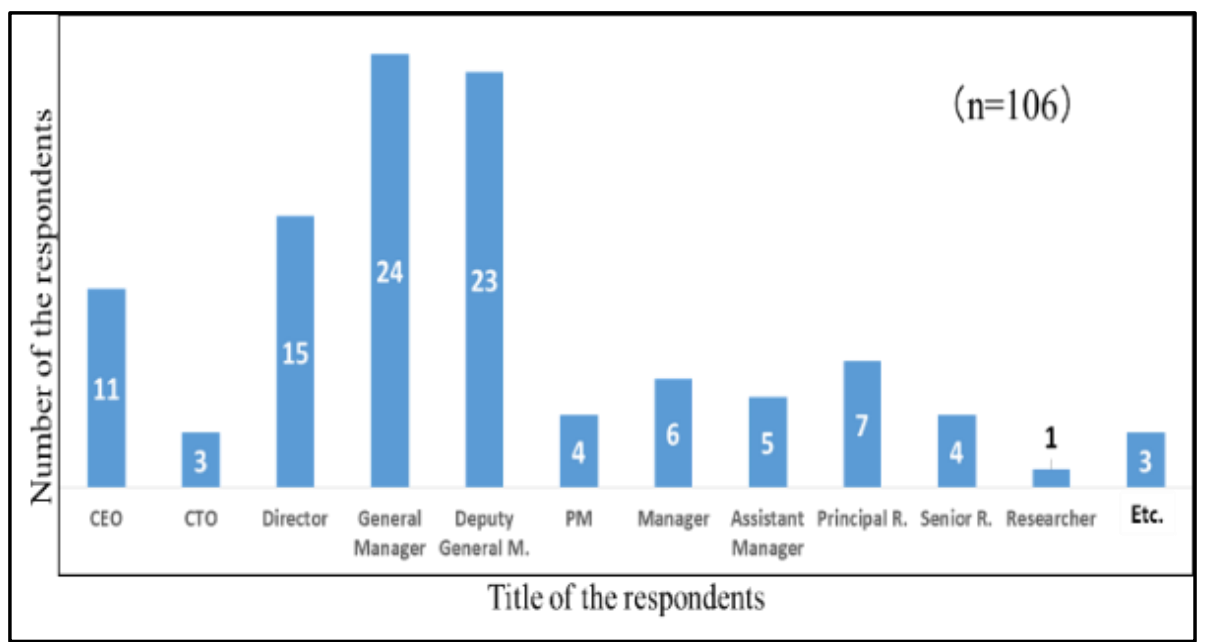

Figure 6. Title of the respondents.

Figure 7 is a pie chart that shows the objectives for NPD $(n=104)$. The objectives for NPD projects were classified using Booz et al.'s method (1982), which is considered as an international standard. Among all the respondents $(\mathrm{n}=104)$, "new to the world" accounted for the most with $56(53.8 \%)$, followed by "new product line" with 24 (23.1\%), "repositioning in the market" with 15 (14.4\%), "product modification" with 8 (7.7\%), and "cost reduction" with $1(1.0 \%)$.

Figure 8 shows the objectives for NPD by firm scale. In small-sized and medium-sized firms, "new to the world" accounted for 56.5\%, which was slightly lower (51.7\%) for large firms and their affiliates, and "new product line" was the highest (27.6\%) for large firms and their affiliates. This graph demonstrates that Korean ICT firms are committing themselves to "new product line" and "new to the world" technologies. In Booz et 
al.'s classification (1982), "'new to the world" means entry into the market for the first time in the world, and, at that time, the authors stated that this category accounted for $10 \%$ of the newly launched products. Compared with the work of Booz et al. (1982), the percentage for "new to the world" in this study seems very high; it is higher than that in the studies of Verworn et al. (2008) and Kim and Yoon (2011) regarding FFE in Japanese and Korean manufacturing firms (Figures 9 and 10).

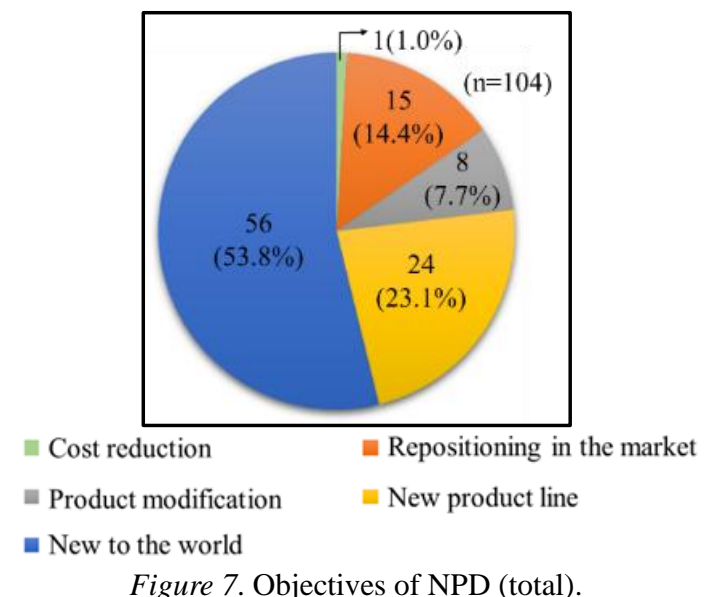

Figure 7. Objectives of NPD (total).

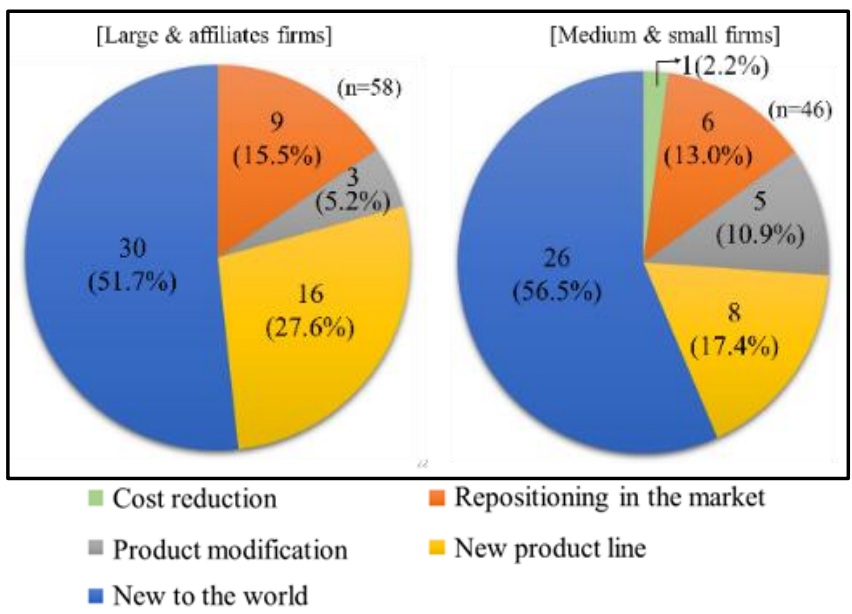

Figure 8. Objectives of NPD by firm scale.

We obtain two implications from the NPD objectives of ICT firms (Figures 7 and 8). First, project managers in Korean ICT firms might consider "new to the world" as "products that their firm has not released in the Korean market" due to translation misunderstanding. Second, there would be many "new to the world" and "new product line" responses as many respondents work for online, mobile gaming, and ICT service firms.

Results of project managers' activities in FFE. To analyze which specific activities project managers at Korean ICT firms focused on in their NPD projects, this study investigated "idea generation", "idea assessment", "market research activities", "technical activities", and "initial project planning". The following sections explain the results for each of these in detail.

\footnotetext{
2 Booz et al.'s classification (1982) consists of six categories with the following percentages: "new to the world" at $10 \%$, "new product lines" at $20 \%$, "additions to existing product lines" at $26 \%$, "improvement to existing products" at $26 \%$, "repositioning" at $7 \%$, and "cost down" at $11 \%$. However, this study combined "new product lines" and "additions to the existing product lines" into "new product lines" and thus used only five categories (Kim \& Yoon, 2011; Verworn et al., 2008).
} 


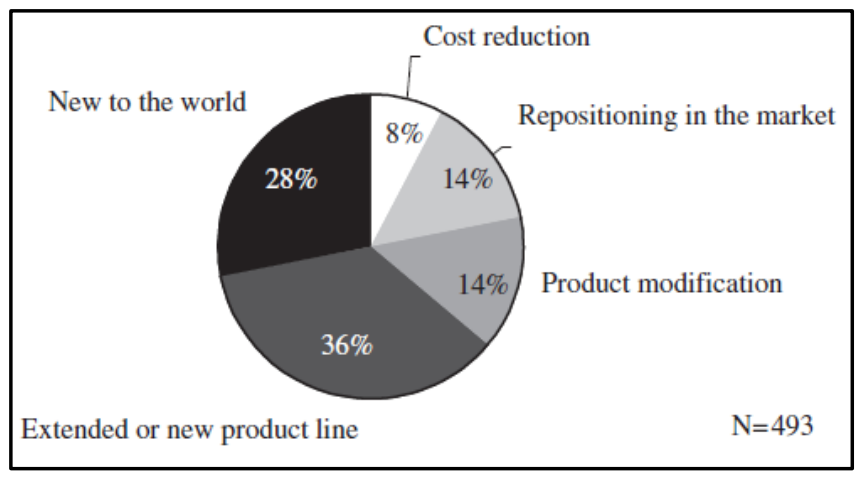

Figure 9. Objectives ratio of NPD by Verworn et al. (2008).

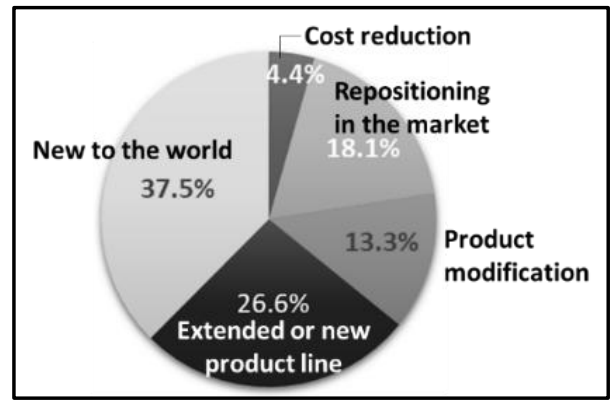

Figure 10. Objectives ratio of NPD by Kim and Yoon (2011).

Idea generation. Table 3 shows the results from all the respondents $(\mathrm{n}=106)$ to the question "Are there systematic and organizational efforts in searching for ideas on new products?" Of all the respondents, 56 (52.8\%) said "Yes", 45 (42.5\%) said "No", and 5 (4.7\%) did not respond. Among the responses from large firms ( $\mathrm{n}=43), 23(53.5 \%)$ answered "Yes", and $19(44.2 \%)$ replied with a "No". Although more than half said "Yes", there were many "No" responses, and it is interesting to note that this finding contrasts with the commonly held view that all large firms search for ideas systematically. When it comes to small firms ( $\mathrm{n}=37$ ), $21(56.8 \%)$, or more than half, said "No". Looking at the survey results, one might argue that there is no difference in idea generation between large and small firms. To the question "Where does your company search for new product ideas?" $(\mathrm{n}=106), 65$ of the respondents $(61.3 \%)$ said "inside the firm", $5(4.7 \%)$ said "outside the firm", 7 (6.6\%) said "both", 25 (23.6\%) said "no idea searching", and 4 (3.8\%) did not respond. Regarding large firms ( $(\mathrm{=}=43)$, only $15(34.9 \%)$ said "we do not search for ideas", another unexpected result like the question about searching for a systematic idea. This suggests that the project managers at ICT firms are internally exploring new product ideas.

Table 3

Systematic Idea Searching and Idea Searching Method

\begin{tabular}{llllllllll}
\hline \multirow{2}{*}{ Firm size } & \multirow{3}{*}{ Respondents } & \multicolumn{3}{c}{ Systematic idea searching } & \multicolumn{5}{c}{ Idea searching method } \\
\cline { 3 - 9 } & Yes & No & N/A & $\begin{array}{l}\text { Inside the } \\
\text { firm }\end{array}$ & $\begin{array}{l}\text { Outside } \\
\text { the firm }\end{array}$ & Both & $\begin{array}{l}\text { No idea } \\
\text { searching }\end{array}$ & N/A \\
\hline Large firms & 43 & 23 & 19 & 1 & 21 & 2 & 3 & 15 & 2 \\
Affiliates & 15 & 12 & 2 & 1 & 11 & 1 & 2 & 1 & 0 \\
Medium firms & 11 & 7 & 3 & 1 & 9 & 0 & 0 & 2 & 0 \\
Small firms & 37 & 14 & 21 & 2 & 24 & 2 & 2 & 7 & 2 \\
Total & 106 & 56 & 45 & 5 & 65 & 5 & 7 & 25 & 4 \\
\hline
\end{tabular}


Table 4 shows responses to the question "Is there an individual or a group in your company responsible for the systematic search for new products?" Among all the respondents $(n=106), 39(36.8 \%)$ said "Yes", and 62 (58.5\%) said "No". In large firms $(\mathrm{n}=43), 23(53.5 \%)$, or more than half, said "No". In the responses from large-firm affiliates $(\mathrm{n}=58), 30(51.7 \%)$ said "No". To the question "Do you use a database to store and process ideas for new products?" $(\mathrm{n}=106), 25(23.6 \%)$ said "Yes", $76(71.7 \%)$ said "No", and $5(4.7 \%)$ provided "no answer".

These results imply that Korean ICT firms are not searching for ideas systematically.

Table 4

Results for Any Responsible Individual or Department and Use of the Database System

\begin{tabular}{llllllll}
\hline \multirow{2}{*}{ Firm size } & \multirow{2}{*}{ Respondents } & \multicolumn{3}{c}{ Any responsible individual or department? } & \multicolumn{3}{c}{ Whether to use the database system } \\
\cline { 3 - 8 } & & Yes & No & N/A & Yes & No & N/A \\
\hline Large firms & 43 & 17 & 23 & 3 & 11 & 28 & 4 \\
Affiliates & 15 & 8 & 7 & 0 & 5 & 10 & 0 \\
Medium firms & 11 & 5 & 6 & 0 & 5 & 6 & 0 \\
Small firms & 37 & 9 & 26 & 2 & 4 & 32 & 1 \\
Total & 106 & 39 & 62 & 5 & 25 & 76 & 5 \\
\hline
\end{tabular}

Table 5 shows the responses to "Creative techniques your company regularly applies to develop new product ideas" with the respondents asked to choose from multiple-choice answers. "Brainstorming" was the answer of $74(43.0 \%)$ respondents, followed by "value analysis" for 37 (21.5\%), "Kaizen" for 36 (20.9\%), "others" for $23(13.4 \%)$, and "nothing" for $2(1.2 \%)$. These results demonstrate that project managers prefer brainstorming regardless of firm size.

Table 5

Idea Development Method by Firm Size

\begin{tabular}{|c|c|c|c|c|c|c|}
\hline \multirow{2}{*}{ Firm size } & \multirow{2}{*}{ Respondents } & \multicolumn{5}{|c|}{ Idea development method $(\mathrm{n}=172)$} \\
\hline & & Brainstorming & Value analysis & Kaizen & Others & Nothing \\
\hline Large firms & 42 & 32 & 14 & 18 & 10 & 0 \\
\hline Affiliates & 15 & 13 & 4 & 3 & 4 & 0 \\
\hline Medium firms & 9 & 7 & 5 & 2 & 0 & 1 \\
\hline Small firms & 37 & 22 & 14 & 13 & 9 & 1 \\
\hline Total & 103 & 74 & 37 & 36 & 23 & 2 \\
\hline
\end{tabular}

Idea assessment. Figure 11 shows responses to the question "In your company, are new product ideas typically assessed by an individual or a group?" Among all the respondents ( $\mathrm{n}=106), 18$ said "individual", 43 said "group", and 45 said "both applicable".

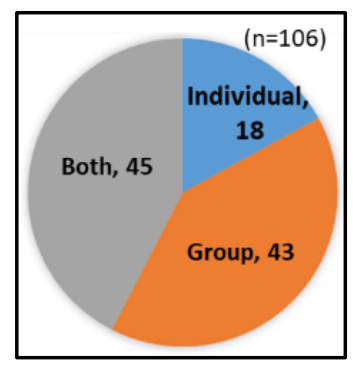

Figure 11. Idea assessor. 
Figure 12 shows the responses to the question "Is upper management typically involved in assessing new product ideas?" Among all the respondents $(n=106), 77$ (72.6\%) said "Yes", 24 (22.6\%) said "sometimes", and $5(4.7 \%)$ said "No". Table 6 lists results by firm size for whether there is any involvement from middle- or higher-level managers among all the respondents $(n=106)$. It shows that regardless of firm size, middle- or higher-level managers are involved in idea assessment in most firms.

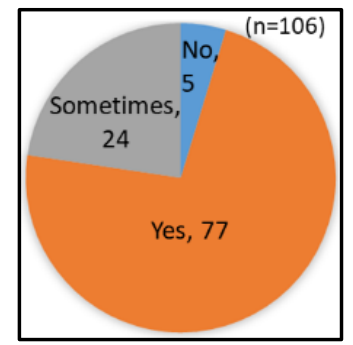

Figure 12. Involvement of middle- or higher-level managers.

Table 6

Involvement of Middle-Level or Higher-Level Managers by Firm Size for Idea Assessment

\begin{tabular}{lllll}
\hline \multirow{2}{*}{ Firm size } & \multicolumn{4}{c}{ Involvement of middle- or higher-level managers } \\
\cline { 2 - 5 } & Yes & Sometimes & No & Total respondents \\
\hline Large firms & 35 & 6 & 2 & 43 \\
Affiliates & 8 & 6 & 1 & 15 \\
Medium firms & 8 & 2 & 1 & 11 \\
Small firms & 26 & 10 & 1 & 37 \\
Total & 77 & 24 & 5 & 106 \\
\hline
\end{tabular}

Figure 13 shows the results for the question "Do you weigh such different (economic and technical) criteria according to their importance?" Among all the respondents, 62 said "Yes", 21 said "sometimes", and 23 said "No".

Figure 14 illustrates responses to the question "Are new product ideas assessed by an interdisciplinary team?" among all the respondents $(\mathrm{n}=106)$ : $53(50 \%)$ said "Yes", $24(22.6 \%)$ said "sometimes", and 29 (27.4\%) said "No". Table 7 lists the cross-analysis results by firm size for the multiple-choice question "If yes, which functions are typically represented in such a team?" Among those who responded, "Yes" $(\mathrm{n}=53)$ in the previous question: "Marketing" accounted for 32, followed by "R\&D" with 30, "Sales" with 29, "After Service" with 7 , "Others" with 8 , and "N/A" with 1 . This suggests that regardless of firm size teams in frequent contact with customers participate in the assessment of ideas.

Figure 15 offers results for the question "Do you use technical criteria in your company to assess new product ideas?" with 27 (25.5\%) saying "Yes", 21 (19.8\%) "sometimes", and 58 (54.7\%) "No". Figure 16 presents responses to the question "If yes, what technical criteria are regularly used in your company to assess new product ideas?" (multiple choice, $\mathrm{n}=37$ ): 25 said "technical feasibility", 8 said "availability of required technology inside my firm", and 4 said "others".

Market research activities. Figure 17 shows the results for the question "How often are you in direct contact with customers/users to develop and evaluate new product ideas?" with 38 (35.8\%) saying "Very often", 57 (53.8\%) saying "Sometimes", and 11 (10.4\%) saying "Very seldom". As shown in Table 8, we asked those who responded with "very often" $(\mathrm{n}=38)$ to answer a multiple-choice question. The table shows the cross-analysis 
results by firm size for the frequency of customer interaction in departments or divisions: "Marketing" accounted for 17, followed by "After Service" with 14, "Sales" with 13, "R\&D" with 8, and "Others" with 6.

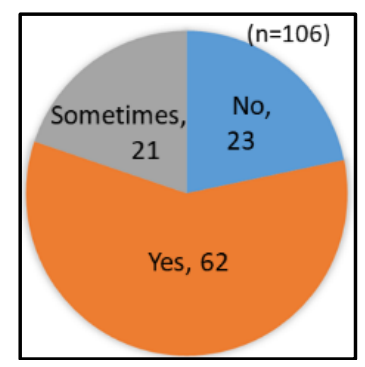

Figure 13. Additional weights.

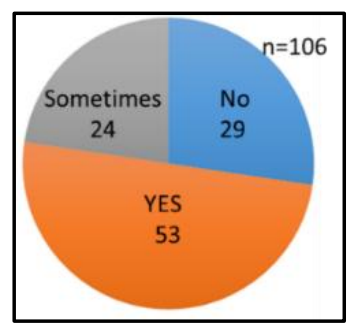

Figure 14. Interdisciplinary team?

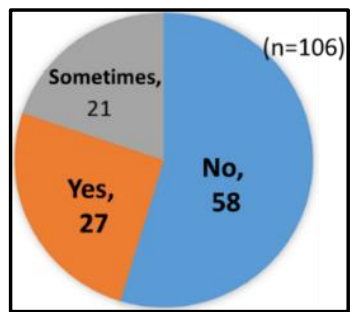

Figure 15. Use of technical criteria?

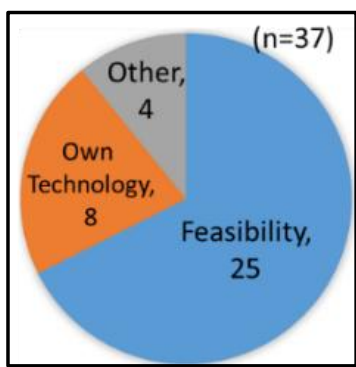

Figure 16. What technical criteria do you use?

Table 7

Cross-Analysis Results by Firm Size With Teams in Other Departments or Divisions

\begin{tabular}{|c|c|c|c|c|c|c|c|}
\hline \multirow{2}{*}{ Firm size } & \multicolumn{6}{|c|}{ Team in other department or division } & \multirow{2}{*}{$\begin{array}{l}\text { Total } \\
\text { respondents }\end{array}$} \\
\hline & Marketing & Sales & $\mathrm{R} \& \mathrm{D}$ & After service & Other & N/A & \\
\hline Large firms & 14 & 9 & 13 & 1 & 3 & - & 22 \\
\hline Affiliates & 4 & 4 & 5 & 2 & 1 & - & 7 \\
\hline Medium firms & 3 & 4 & 4 & 2 & 1 & - & 6 \\
\hline Small firms & 11 & 12 & 8 & 2 & 3 & 1 & 18 \\
\hline Total & 32 & 29 & 30 & 7 & 8 & 1 & 53 \\
\hline
\end{tabular}


Table 8

Customer Contact Frequency for Departments or Divisions by Firm Size

\begin{tabular}{|c|c|c|c|c|c|}
\hline \multirow{2}{*}{ Firm size } & \multicolumn{5}{|c|}{ Frequency of customer contact } \\
\hline & Marketing & Sales & $\mathrm{R} \& \mathrm{D}$ & After service & Others \\
\hline Large firms & 10 & 4 & 2 & 4 & 4 \\
\hline Affiliates & 0 & 1 & 1 & 2 & 1 \\
\hline Medium-sized & 3 & 3 & 1 & 3 & 1 \\
\hline Small firms & 4 & 5 & 4 & 5 & 0 \\
\hline Total & 17 & 13 & 8 & 14 & 6 \\
\hline
\end{tabular}

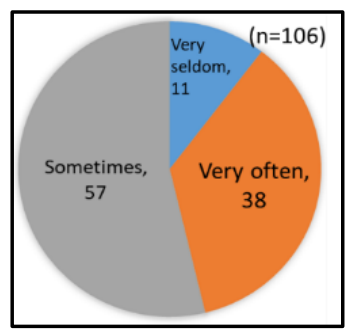

Figure 17. Frequency of customer contact.

Table 9 provides results for the question "What are the criteria to select customers/users that you contact?" (multiple choice, $\mathrm{n}=103$ ), in terms of idea development or assessment for new products. "Importance" accounted for 53 (51.5\%), followed by "solve the problem" with 47 (45.6\%), and "dissatisfied" with 39 (37.9\%).

As shown in Table 10, we requested that respondents answer the multiple-choice question "Market-related sources?" to develop ideas for new products: "Analysis of competitors and their product" accounted for 83 respondents and was the most preferred market resource regardless of firm size. This was followed by "Market research by external entities" and "Customer survey" each with 67 each, "Complaints" with 63, and "Direct Contact" with 62 .

Table 9

Customer Selection Criteria to Develop or Assess Ideas

\begin{tabular}{lllllllll}
\hline Firm size & Dissatisfied & $\begin{array}{l}\text { Solve the } \\
\text { problem }\end{array}$ & $\begin{array}{l}\text { Knowledge of } \\
\text { customer/user }\end{array}$ & Importance & $\begin{array}{l}\text { Good } \\
\text { relationship }\end{array}$ & Others & $\begin{array}{l}\text { Not } \\
\text { used }\end{array}$ & $\begin{array}{l}\text { Total } \\
\text { respondents }\end{array}$ \\
\hline Large firms & 13 & 17 & 2 & 17 & 1 & 7 & 2 & 41 \\
Affiliates & 6 & 11 & 3 & 11 & 1 & 2 & 0 & 15 \\
Medium-sized firm & 5 & 5 & 2 & 6 & 2 & 0 & 0 & 10 \\
Small firms & 15 & 14 & 4 & 19 & 6 & 3 & 2 & 37 \\
Total & 39 & 47 & 11 & 53 & 10 & 12 & 4 & 103 \\
\hline
\end{tabular}

Table 10

Market-Related Resources by Firm Size

\begin{tabular}{|c|c|c|c|c|c|c|c|c|}
\hline Firm size & $\begin{array}{l}\text { Direct } \\
\text { contact }\end{array}$ & Complaints & $\begin{array}{l}\text { Customer } \\
\text { surveys }\end{array}$ & $\begin{array}{l}\text { Market } \\
\text { research by } \\
\text { externals }\end{array}$ & $\begin{array}{l}\text { Analysis of } \\
\text { competitors and } \\
\text { their products }\end{array}$ & Others & $\begin{array}{l}\text { Not } \\
\text { used }\end{array}$ & $\begin{array}{l}\text { Total } \\
\text { respondents }\end{array}$ \\
\hline Large firms & 21 & 29 & 34 & 33 & 36 & 5 & 1 & 42 \\
\hline Affiliates & 8 & 9 & 9 & 10 & 11 & 1 & 0 & 15 \\
\hline Medium-sized firms & 10 & 8 & 8 & 6 & 9 & 0 & 0 & 11 \\
\hline Small firms & 23 & 17 & 16 & 18 & 27 & 0 & 0 & 37 \\
\hline Total & 62 & 63 & 67 & 67 & 83 & 6 & 1 & 105 \\
\hline
\end{tabular}


Figure 18 shows responses to the question "Does your company systematically integrate customer requirements into the definition of the new product concept?" $(\mathrm{n}=106)$ : $40(37.7 \%)$ said "very often", $54(50.9 \%)$ said "sometimes", and $12(11.3 \%)$ said "seldom". This result demonstrates that project managers incorporate customer requirements into new product concepts. Figure 19 displays the results for the question "Does your company systematically translate customer requirements into technical specifications?" from the respondents $(\mathrm{n}=104)$ : $30(28.8 \%)$ said "Yes", 55 (52.9\%) said "sometimes", and 19 (18.3\%) said "No". This result suggests that project managers at Korean ICT firms try to implement customer requirements into their technology development projects. As shown in Table 11, we asked those who said "Yes" to the question "Does your company systematically translate customer requirements into technical specifications?" $(\mathrm{n}=30)$, to provide answers to a multiple-choice question, "If yes, which methods or tools typically apply during pre-development?" The results showed that 9 respondents chose "none", followed by 9 for "QFD", 1 for "TRIZ", and 8 for "Others".

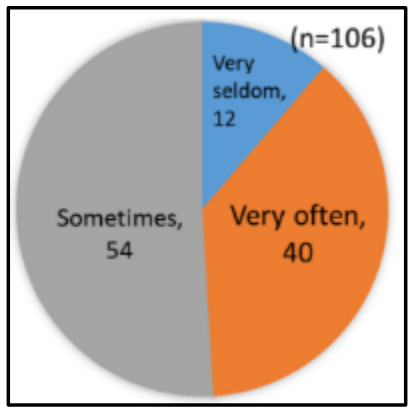

Figure 17. Whether to integrate customer requirements into the definition of a new product concept?

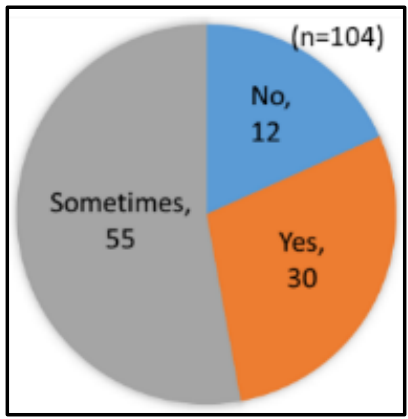

Figure 18. Whether to translate customer requirements into technical specifications?

Table 11

Tools Used to Incorporate Customer Requirements Into Technical Specifications

\begin{tabular}{|c|c|c|c|c|c|}
\hline Firm size & None & QFD & TRIZ & Others & Respondent total \\
\hline Large firms & 4 & 5 & 1 & 5 & 13 \\
\hline Affiliates & 2 & 2 & 0 & 1 & 5 \\
\hline Medium-sized firms & 1 & 1 & 0 & 2 & 4 \\
\hline Small firms & 2 & 1 & 0 & 0 & 3 \\
\hline N/A & - & - & - & - & 5 \\
\hline Total & 9 & 9 & 1 & 8 & 30 \\
\hline
\end{tabular}

Technical activities. Table 12 provides results to the question "Which of the following methods or tools does your company typically apply during pre-development?" $(\mathrm{n}=102)$ : "None" accounted for $47(46.1 \%)$ respondents, followed by "Simulation" and "Others" 26 each (25.5\%), and "3D Printing" with 3 (2.9\%). 
Respondents who chose "3D Printing" were from small firms. Respondents who chose "Others" said that they used prototypes, mockups, proof of concept, wireframes, analysis of competitors' products and identification of their functions, testing with similar products at home and abroad, design thinking, and JIRA (a software developed by Atlassian that allows bug tracking, issue tracking, and agile project management).

Table 12

Methods or Tools Used for the New Product Development Project's Fuzzy Front End

\begin{tabular}{llllll}
\hline Firm size & Simulation & 3D Printing & Others & None & Total respondents \\
\hline Large firms & 10 & 0 & 12 & 18 & 40 \\
Affiliates & 1 & 0 & 8 & 5 & 14 \\
Medium-sized firms & 5 & 0 & 0 & 5 & 10 \\
Small firms & 10 & 3 & 6 & 47 & 38 \\
Total & 26 & 3 & 26 & 47 & 102 \\
\hline
\end{tabular}

Initial project planning. Figure 20 shows results for the question "Does your company systematically plan a project prior to the start of development?" $(\mathrm{n}=105)$ : "Yes" accounted for $63(60.0 \%)$, followed by "Sometimes" with 33 (31.4\%), and "No" with $9(8.6 \%)$. This result demonstrates that most project managers in Korean ICT firms establish a plan in the initial project phase.

Figure 21 depicts responses to the question "Does your company use of project management software?" (n = 104): "Yes" accounted for 31 (29.8\%) and "No" 73 (70.2\%). This result implies that project managers in Korean ICT firms do not often use project management software. Table 13 shows the cross-analysis by firm size to the question from Figure 20. The results indicate that all firms, whether they answered "Always" or "Sometimes", carry out initial planning regardless of size.

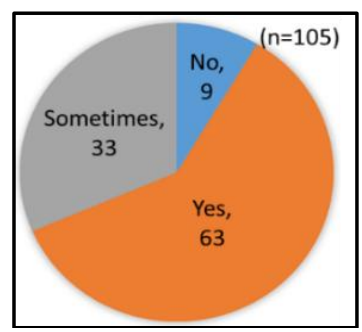

Figure 19. Whether to systematically establish a project plan before new product development?

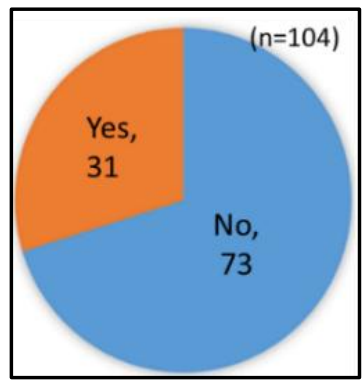

Figure 20. Whether to use software for project planning?

Table 14 summarizes "Establishment of Initial New Product Development Project Planning" for "Always $(\mathrm{n}=63)$ " and "Sometimes $(\mathrm{n}=33)$ " from Table 13 and shows information for Initial New Product Development Project Planning by Firm Size. Out of 96 respondents, 85 provided information about initial planning and 11 did not respond. The 85 respondents were asked a multiple-choice question regarding 
information about initial planning. The results showed that "milestones" were preferred by 60 respondents across the firms, followed by "cost plan" with 49, "required staff for the project" with 42 , "work packages" with 36, "Gantt charts" with 21, and "network diagrams" with 7.

Table 13

Whether They Establish Initial New Product Development Project Planning by Firm Size

\begin{tabular}{|c|c|c|c|c|c|}
\hline \multirow{2}{*}{ Firm size } & \multicolumn{3}{|c|}{ Project planning } & \multirow{2}{*}{$-\mathrm{N} / \mathrm{A}$} & \multirow{2}{*}{ Total respondents } \\
\hline & Always & Sometimes & No & & \\
\hline Large & 27 & 11 & 5 & - & 43 \\
\hline Affiliates & 11 & 3 & 1 & - & 15 \\
\hline Medium-sized & 8 & 3 & 0 & - & 11 \\
\hline Small firms & 17 & 16 & 3 & 1 & 37 \\
\hline Total & 63 & 33 & 9 & 1 & 106 \\
\hline
\end{tabular}

Table 14

Information for Initial New Product Development Project Planning by Firm Size

\begin{tabular}{lllllllllllllll}
\hline Project establishment & \multicolumn{3}{c}{ Milestones } & \multicolumn{2}{c}{$\begin{array}{l}\text { Work } \\
\text { packages }\end{array}$} & Cost plan & Staff & & Gantt charts & $\begin{array}{l}\text { Network } \\
\text { diagram }\end{array}$ \\
\hline & $\begin{array}{l}\text { Always + } \\
\text { Sometimes }\end{array}$ & N/A & Y & N & Y & N & Y & N & Y & N & Y & N & Y & N \\
\hline Large firms & 38 & 5 & 29 & 10 & 18 & 21 & 26 & 13 & 19 & 20 & 8 & 31 & 3 & 36 \\
Affiliates & 14 & 1 & 10 & 2 & 6 & 6 & 6 & 6 & 5 & 7 & 4 & 8 & 1 & 11 \\
Medium-sized & 11 & 0 & 3 & 4 & 2 & 5 & 6 & 1 & 5 & 2 & 3 & 4 & 1 & 6 \\
Small firms & 33 & 3 & 18 & 9 & 10 & 17 & 11 & 16 & 13 & 14 & 6 & 21 & 2 & 25 \\
Total & 96 & 9 & 60 & 25 & 36 & 49 & 49 & 36 & 42 & 43 & 21 & 64 & 7 & 78 \\
\hline
\end{tabular}

Table 15

Whether They Use Software for Project Planning by Firm Size

\begin{tabular}{lllll}
\hline Firm size & Yes & No & N/A & Total respondents \\
\hline Large firms & 9 & 33 & 1 & 42 \\
Affiliates & 5 & 10 & 0 & 15 \\
Medium firms & 4 & 6 & 1 & 10 \\
Small firms & 13 & 24 & 0 & 37 \\
Total & 31 & 73 & 2 & 104 \\
\hline
\end{tabular}

Table 15 shows the cross-analysis results for the question from Figure $21(\mathrm{n}=104)$.

When it comes to project managers at large firms $(n=42), 33(78.6 \%)$ said "No", demonstrating that they seldom use project management software when establishing a project plan.

This result is contrary to the belief that large firms and affiliates manage projects systematically. This means that they do not prefer project management software. From the responses, we find that the use of project management software is not preferred because of the time required to manage it. This result suggests that they use their own methods to manage projects.

\section{Conclusion}

This study is significant because it focuses on Korean ICT firms and clarifies their specific activities in the FFE phase for the first time. These FFE activities in NPD, which have a positive effect on corporate governance, have not been identified in earlier causation analysis studies that examine the Korean 
manufacturing industry.

To summarize, the followings are this study's findings. First, Korean ICT firms do not systematically manage idea searching in the FFE phase, regardless of firm size. For instance, there are many negative responses to questions on the existence of any department in charge of idea searching, the use of a database system, and tools used for technical development activities. In addition, when it comes to project planning, more than half of the small firms said that they used project management software. In contrast, project managers at larger firms did not prefer such software. Second, idea searching was mostly performed inside the company, with brainstorming being the most preferred method for idea searching, while other departments or divisions' assessed ideas.

For idea assessment, the respondents frequently communicate with departments or divisions that interact with customers.

Third, middle-level and higher-level managers have involved in idea assessment and the management had extensive interest in NPD. Fourth, the respondents actively performed market survey activities such as analyzing competitors' products and directly interacting with customers, to incorporate market information.

Fifth, NPD project managers in Korean ICT firms were committed to initial planning in the FFE.

Unexpected findings were identified that were contradictory to the implicit belief that large firms systematically manage NPD projects because they have plenty of management resources.

Although these results do not generalize the FFE activities of Korean ICT firms, they are of academic significance after considering the fact that more than $50 \%$ of respondents are large and affiliates firms. This implies that Korean ICT firms are flexible in project management. This study supports the arguments made by Mammetseyidov and Nagahira (2015) in their comparative study of Korean and Japanese manufacturing firms. They concluded that Korean firms had flexible systems for project implementation, which allowed them to change their initial plans based on changes in the business environment, thereby suggesting that ICT firms had flexible management systems as well.

Furthermore, this study supports previous findings that Korean manufacturing firms focus more on activities that reduce market uncertainty, than on activities that reduce technical uncertainty during the FFE phase.

\section{Limitations and Future Direction}

This study has the following two limitations. First, it is difficult to generalize this study's results on ICT firms' FFE activities due to its limited sample size.

Second, the survey questionnaire developed for manufacturing firms were used for ICT service firms as well.

Thus, we reflected on the feedback from the project managers of the ICT service firms after the pilot test, and composed the new survey questionnaire, in which we indicated both "new service development" and "new product development".

Accordingly, the limitation of this study is that it cannot identify the activities during the FFE phase for ICT service firms.

In the future, further studies need to be conducted to identify the differences in FFE activities between ICT manufacturing firms and ICT service firms. 


\section{References}

Baker, N. R., Green, S. G., \& Bean, A. S. (1985). How management can influence the generation of ideas. Research Management, 28(6), 35-42.

Balachandra, R., \& Friar, J. H. (1997). Factors for success in R\&D projects and new product innovation: A contextual framework. IEEE Transactions on Engineering Management, 44(3), 276-287.

Balbontin, A., Yazdani, B., Cooper, R., \& Souder, W. E. (1999). New product development success factors in American and British firms. International Journal of Technology Management, 17(3), 259-280.

Booz, Allen, \& Hamilton. (1982). New product management for the 1980s. New York: Booz, Allen \& Hamilton, Inc.

Cooper, R. G. (1988). Predevelopment activities determine new product success. Industrial Marketing Management, 17(3), 237-247.

Cooper, R. G., \& Kleinschmidt, E. J. (1987). What makes a new product a winner: Success factors at the project level. $R \& D$ Management, 17(3), 175-189.

Cooper, R. G., \& Kleinschmidt, E. J. (1990). New products: The key factors in success. Chicago: American Marketing Association.

Cooper, R. G., \& Kleinschmidt, E. J. (1994). Determinants of timeliness in product development. Journal of Product Innovation Management, 11(5), 381-396.

Dwyer, L., \& Mellor, R. (1991). Organizational environment, new product process activities, and project outcomes. Product Innovation Management, 8(1), 39-48.

Geschka, H. (1992). Creativity techniques in product planning and development: A view from West Germany. In S. J. Parnes (Ed.), Source book of creative problem-solving (pp. 282-298). Buffalo: Creative Education Foundation Press.

Herstatt, C., Verworn, B., \& Nagahira, A. (2004). Reducing project related uncertainty in the "fuzzy front end" of innovation: A comparison of German and Japanese product innovation projects. International Journal of Product Development, 1(1), 43-65.

Johne, F. A., \& Snelson, P. A. (1988). Success factors in product innovation-A selective review of the literature. Journal of Product Innovation Management, 5(2), 114-128.

Khurana, A., \& Rosenthal, S. R. (1998). Towards holistic "front ends" in new product development. Journal of Product Innovation Management, 15(1), 57-74.

Kim, K. H., \& Yoon, H. J. (2011). R\&D plan's influence for the management performance-Focus on fuzzy front end model. Productivity Review, 25(4), 317-344.

Maidique, M. A., \& Zirger, B. J. (Nov. 1984). A study of success and failure in product innovation. IEEE Transactions on Engineering Management, EM-31(4), 192-203.

Mammetseyidov, R., \& Nagahira, A. (2015). Comparative study on FFE activities between Japanese and Korean NPD project success. Management Studies, 3(9), 247-261.

Mansfield, E., \& Samuel, W. (1975). Organizational and strategic factors associated with probabilities of success in industrial R\&D. The Journal of Business, 48(2), 179-198.

Ministry of Science and ICT. (2018a). 2017 annual report on the promotion on the Korean ICT industry.

Ministry of Science and ICT. (2018b). Information and communication technology industry statistics. Retrieved from http://kosis.kr/statHtml/statHtml.do?orgId=127\&tblId=DT_12007_N001\&vw_cd=MT_ZTITLE\&list_id=115_12007\&seqNo $=\& l a n g \_$mode $=$ko\&language $=$kor\&obj_var_id=\&itm_id=\&conn_path=MT_ZTITLE $($access December 1,2018$)$

Mishra, S., Kim, D., \& Lee, D. H. (1996). Factors affecting new product success: Cross-country comparison. Journal of Product Innovation Management, 13(6), 530-550.

Moenaert, R. K., De Meyer, A., Souder, W. E., \& Deschoolmeester, D. (1995). R\&D/Marketing communication during the fuzzy front-end. IEEE Transactions on Engineering Management, 42(3), 243-258.

Mullins, J. W., \& Sutherland, D. J. (1998). New product development in rapidly changing markets: An exploratory study. Journal of Product Innovation Management, 15(3), 224-236.

Nagahira, A., Kim, K. K., Yoon, H. J., Ishihara, S., Chiba, Y., Tanaka, Y., \& Miura, A. (2015). Comparative study on FFE activities between Korean and Japanese new product projects. International Journal of Technology Marketing, 10, 67-94.

Nakata, C., Im, S., Park, H., \& Ha, Y. W. (2006). Antecedents and consequence of Korean and Japanese new product advantage. Journal of Business Research, 59, 28-36.

Pinto, J. K., \& Slevin, D. P. (1988). Project success: Definitions and measurement techniques. Project Management Journal, 19(1), 67-72. 
Rochford, L. (1991). Generating and screening new product ideas. Industrial Marketing Management, 20(4), $287-296$.

Rubinstein, A. H. (1994). At the front end of the R\&D/innovation process-Idea development and entrepreneurship. International Journal of Technology Management, 9(5-7), 652-677.

Smith, P. G., \& Reinertsen, D. G. (1991). Developing products in half the time. New York: Van Nostrand Reinhold Publishers.

Song, X. M., \& Montoya-Weiss, M. M. (2001). The effect of perceived technological uncertainty on Japanese new product development. Academy of Management Journal, 44(1), 61-80.

Song, X. M., \& Parry, M. E. (1996). What separates Japanese new product winners from losers. Journal of Product Innovation Management, 13(5), 422-439.

Song, X. M., \& Parry, M. E. (1997). A cross-national comparative study of new product development processes: Japan and the United States. Journal of Marketing, 61(2), 1-18.

Verganti, R. (1999). Planned flexibility: Linking anticipation and reaction in product development projects. Journal of Product Innovation Management, 16(4), 363-376.

Verworn, B., Herstatt, C., \& Nagahira, A. (2008). The fuzzy front end of Japanese new product development projects: Impact on success and differences between incremental and radical projects. $R \& D$ Management, 38(1), 1-19.

Wind, Y., \& Mahajan, V. (1988). New product development process: A perspective for reexamination. Journal of Product Innovation Management, 5(4), 304-310.

Yoon, H. J., Nagahira, A., \& Ishida, S. I. (Nov. 2016). The impact of management during "fuzzy front end" on reducing uncertainty of NPD process in Korean manufacturing companies. Japan Association for Management Systems, 33(2), 119-129. 